\title{
Pengembangan Media Audio Visual Berbasis Kearifan Lokal Pada Tema 1 Indahnya Kebersamaan Kelas IV SDN Tahun Pelajaran 2019/2020
}

\author{
Muhammad Sururuddin $^{1}$, Burhanuddin ${ }^{2}$, Zohrani $^{3}$, Afwani Dwi Safitri ${ }^{4}$ \\ Pogram Studi PGSD Universitas Hamzanwadi ${ }^{1,2,3,4}$ \\ Surur_life@yahoo.co.id ${ }^{1}$,Burhanuddin.mha@gmail.com², \\ Zohranis@gmail.com ${ }^{3}$, afwani.guafa14@gmail.com ${ }^{4}$
}

\begin{abstract}
Abstrak
Tujuan penelitian ini adalah untuk mengembangkan media audio visual berbasis kearifan lokal pada Tema 1 Indahnya Kebersamaan dan bagaimana hasil pengembangan dari perancangan media berbasis kearifan lokal yang telah didesain. Penelitian dan pengembangan yang digunakan mengacu pada model pengembangan Sugiyono. Prosedur pengembangan yang digunakan dibatasi sampai enam tahapan yaitu (1) potensi dan masalah, (2) pengumpulan data, (3) desain produk, (4) validasi desain, (5) revisi desain, dan (6) uji coba produk. Jumlah siswa yang dijadikan subyek uji coba pada penelitian ini adalah 36 orang yang diambil dari kelas IV SDN 1 Danger tahun pelajaran 2019/2020. Dari hasil analisis data menunjukkan bahwa media yang dirancang berkategori valid dengan kualitas bahan ajar baik. Hal ini dibuktikan dengan hasil validasi dari ahli materi dengan skor rata-rata 4,9 dan ahli tampilan dengan skor rata-rata 3,5. Data lain sebagai pendukung hasil validasi ini dapat dilihat dari hasil respon siswa yang memberikan jawaban "ya" dengan respon sebesar 91,3\% untuk uji coba serta hasil dari tes belajar siswa dalam belajar menggunakan media audio visual berbasis kearifan lokal adalah baik dengan ketuntasan klasikal siswa mencapai $80 \%$. Ini berarti bahwa pengembangan media audio visual berbasis kearifan lokal efektif digunakan dalam mengajarkan tema 1 Indahnya Kebersamaan.
\end{abstract}

Kata kunci: Pengembangan, Media Audio Visual, Kearifan Lokal 


\section{PENDAHULUAN}

Pendidikan merupakan salah satu faktor yang sangat penting untuk terciptanya masyarakat yang berkualitas. Pendidikan dapat diartikan sebagai usaha sadar dan terencana yang dilakukan seorang pendidik untuk mewujudkan suasana belajar dan proses pembelajaran agar peserta didik secara aktif dapat mengembangkan potensi dirinya untuk memiliki kekuatan spiritual keagamaan, pengendalian diri, kepribadian, kecerdasan, akhlak mulia, serta keterampilan yang diperlukan dirinya, masyarakat, bangsa dan Negara. Ini diharapkan akan dapat mewujudkan teciptanya masyarakat masa depan yang mampu bersaing dalam bebagai bidang.

berdasarkan hasil observasi lapangan yang dilakukan peneliti terdapat bebeapa permasalahan yaitu: 1. Penggunaan media disekolah masih kurang dan terbatas; 2. Guru masih mengandalkan buku paket sehingga siswa kurang bersemangat dalam belajar; 3. Guru belum menggunakan media pendamping yang menyisipkan materi kearifan lokal daerah Lombok; 4. Pengembangan media pembelajaran oleh guru masih belum maksimal.

Melihat permasalahan tersebut, perlu dikembangkannya sebuah media pendamping untuk kegiatan pembelajaran, khususnya pada pada tema 1 kelas IV Indahnya Kebersamaan untuk mengenalkan kearifan lokal Daerah Lombok seperti tradisi, adat istiadat, makanan tradisional dan lain-lain. Salah satu media yang dapat memuat materi tersebut adalah media audio visual berbasis kearifan lokal untuk menunjang pembelajaran.

Menurut Hamdani (2011: 244) “media pembelajaran bisa diartikan sebagai alat yang bisa merangsang siswa dalam melakukan proses belajar”. Hal ini berdasarkan pengertian media yaitu segala sesuatu yang dapat digunakan untuk menyalurkan pesan, merangsang pikiran, perasaan, dan kemauan siswa sehingga mendorong terciptanya proses belajar pada diri siswa. Penggunaan media pembelajaran sangat diperlukan untuk menyalurkan pesan, merangsang fikiran, perasaan, dan kemauan peserta didik serta mengaktifkan pembelajaran dalam memberi tanggapan dan umpan sehingga dapat meningkatkan motivasi dalam belajar. Salah satu media pembelajaran yang efektif diterapkan adalah media Audio Visual.

Menurut Yudhi Munadi (2013: 56) media Audio-Visual, adalah media yang melibatkan indera penglihatan dan pendengaran sekaligus dalam satu 
proses.Sifat pesan yang disalurkan dapat berupa pesan verbal dan non-verbal yang terlihat (dalam bentuk visual) maupun terdengar (dalam bentuk audio).

Secara umum, media pembelajaran dapat dikelompokkan menjadi beberapa bagian yaitu: 1) media hasil teknologi cetak, 2) media hasil teknologi audio visual, 3) media hasil teknologi yang berdasarkan komputer, dan 4) media hasil gabungan teknologi cetak dan komputer. Secara garis besar media pembelajaran dapat dikelompokkan menjadi tiga yaitu media audio, media visual, dan media audio visual. (Arsyad. 2017: 31).

Media audio visual dapat dimanfaatkan secara optimal agar menghasilkan pengalaman pembelajaran yang menyenangkan. Karena media audio visual "mempermudah guru dalam berinteraksi, pemakaiannya efektif dan efisien, praktis, dan lebih cepat dipahami oleh peserta didik. Salah satu bentuk dari media audio visual adalah video pembelajaran" (Rusman dkk, 2013: 218).

Vidio adalah segala sesuatu yang memungkinkan sinyal audio dapat dikombinasikan dengan gambar bergerak. Vidio sebagai media audio visual yang berkenaan dengan apa yang dilihat seperti gambara hidup atau bergerak, proses perekamannya, dan penayangannya yang melibatkan teknologi. (Daryanto, 2013: 88).

Menurut Arsyad (2017) kelebihan video adalah a) video dapat melengkapi pengalaman-pengalaman dasar dari siswa ketika mereka membaca, berdiskusi, praktik, dan lain-lain, b) video dapat menggambarkan suatu proses secara tepat yang dapat disaksikan secara berulang-ulang jika dipandang perlu, c) video menanamkan sikap dan segi-segi afektif lainnya, d) video yang mengandung nilai-nilai positif dapat mengundang pemikiran dan pembahasan dalam kelompok siswa, e) video dapat ditunjukkan kepada kelompok besar atau kecil, kelompok yang heterogen, maupun perorangan, f) dengan kemampuan dan teknik pengambilan gambar, frame demi frame, video yang dalam kecepatan normal memakan waktu satu minggu dapat ditampilkan satu atau dua menit. Sedangkan kelemahan video adalah a) pembuatan video umumnya memerlukan biaya mahal dan waktu yang banyak, b) pada saat video dipertunjukkan, gambar-gambar bergerak terus sehingga tidak semua mampu mengikuti informasi yang ingin disampaikan, c) video yang tersedia tidak selalu sesuai dengan kebutuhan dan tujuan belajar yang diinginkan. 
Pemanfaatan audie visual ini akan sangat membantu kegiatan pengajaran agar menjadi lebih menarik dan efektif teutama dalam memasukkan unsur-unsur kearifan budaya lokal. Menurut Andi dan Syarifuddin (Marfai, 2013: 35) "mendefinisikan kearifan lokal sebagai suatu bentuk tata nilai, sikap, persepsi, perilaku dan respon suatu masyarakat lokal dalam berinteraksi pada suatu sisteam kehidupan dengan alam dan lingkungan tempatnya hidup secara arif”. Makna dan nilai kearifan lokal yang ada dalam masyarakat memiliki tujuan untuk mengembangkan pengetahuan peserta didik yang bersumber pada kearifan lokal masyarakat setempat dan memiliki sikap serta prilaku yang selaras dengan nilai kearifan lokal tersebut.

Menurut Suryono (2012: 15) ciri-ciri kearifan lokal adalah a) Mampu bertahan terhadap budaya luar, b) Memiliki kemampuan untuk mengakomodasi unsur-unsur budaya luar, c) Mempunyai kemampuan mengintegrasikan unsur budaya luar kedalam budaya asli, d) Mempunyai kemampuan mengendalikan dan e) Mampu memberi arah pada perkembangan budaya.

Kearifan lokal dapat berbentuk nilai, norma, etika, kepercayaan, adat-istiadat, hukum, adat, aturan-aturan khusus. Selanjutnya, nilai-nilai yang relevan dengan kearifan lokal, antara lain nilai kejujuran, tanggung jawab, disiplin, kreatif, serta kerja keras (Haryanto, 2019). Dengan demikian dapat dipahami bahwa dalam kearifan lokal tesebut tedapat nilai-nilai dasar kehidupan yang sangat dibutuhkan manusia dalam hidup bermasyarakat, berbangsa, dan bernegara.

Bedasarkan permasalahan tesebut, peneliti mencoba megembangkan Media Audio Visual Berbasis Kearifan Lokal Pada Tema 1 Indahnya Kebersamaan Kelas IV SDN 1 Danger Tahun Pelajaran 2019/2020”.

\section{METODE PENELITIAN}

Penelitian ini menggunakan metode Research and Development" (R\&D) yaitu suatu proses untuk mengembangkan suatu produk baru atau menyempurnakan produk yang telah ada, yang dapat dipertanggungjawabkan (Nana Syaodih, 2013: 164). 
Adapun tahapan pegembangan produk penelitian ini meliputi enam tahapan yaitu:

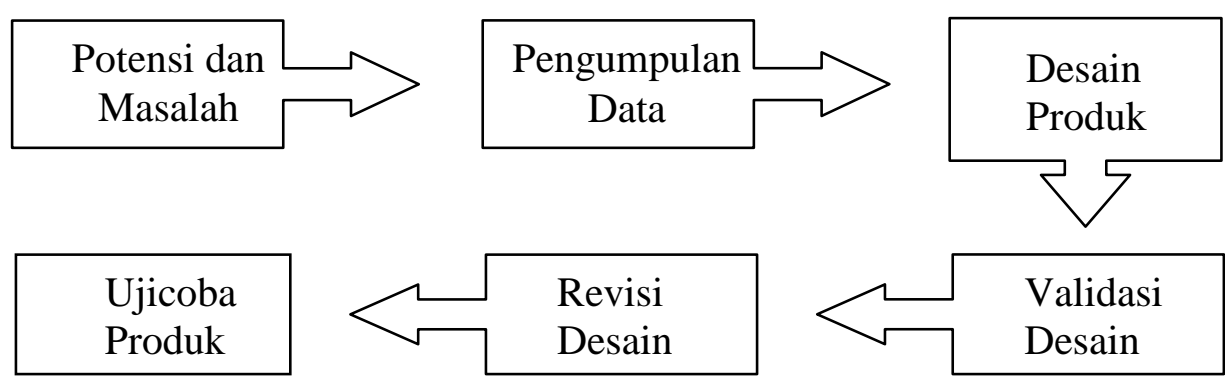

Gambar. 1. Tahapan pengembangan media audio visual

Instrument yang digunakan dalam penelitian ini yaitu: 1. Lembar validari tim ahli. Lembar validasi ahli digunakan untuk mengumpulkan data validasi awal produk. Dalam hal ini lembar validasi akan divalilidasikan oleh ahli media dan ahli materi; 2. Angket respon siswa. Angket respon siswa digunakan untuk mendapatkan informasi tentang respon dari peserta didik terkait dengan media audio visual berbasis kearifan lokal yang kan diujicobakan dalam proses pembelajaran. 3. Tes Belajar. Adapun tes yang digunakan untuk mengetahui ketuntasan hasil belajar peserta didik setelah menggunakan produk yang dikembangkan berupa soal pilihan ganda sebanyak 25 butir untuk memberikan kesempatan kepada peserta didik untuk menjawab pertanyaan yang telah tersedia didalam media audio visual berbasis kearifan lokal daerah Lombok.

Tahapan yang akan dilakukan dalam analisis data yaitu: Angket Validasi Tim Ahli, Angket Respon Siswa, dan Analisis Tes Hasil Belajar.

\section{Angket Validasi Tim Ahli}

Data berupa skor tanggapan validator yang dipilih dalam bentuk kategori yang terdiri dari lima pilihan tanggapan tentang kualitas produk media audio visual berbasis kearifan lokal yang dikembangkan, yaitu sangat baik (5), baik (4), cukup baik (3), kurang baik (2), sangat kurang baik (1). Data tersebut diubah menjadi data interval. Skor yang diperoleh kemudian dikonverensikan menjadi data kualitatif skala lima.

\section{Angket Respon Siswa}

Data yang diperoleh dari hasil angket respon siswa kemudian akan dianalisis menggunakan data kuantitatif, untuk menguji respon siswa dan kelayakan tentang 
produk yang dikembangkan. Jawaban angket respon siswa menggunakan angket skala guttman yang menggunakan dua kategori yang dibuat dalam bentuk pilihan, yaitu pilihan "Ya atau Tidak".

\section{Analisis Tes Hasil Belajar}

Analisis tes hasil belajar siswa perlu dilakukan untuk mengetahui ketuntasan hasil belajar siswa, setelah dikembangkan media audio visual berbasis kearifan lokal. Untuk mengetahui ketuntasan hasil belajar siswa setelah menggunakan produk yang dikembangkan berupa media audio visual berbasis kearifan lokal.

\section{HASIL DAN PEMBAHASAN}

Bedasarkan hasil penelitian pengembangan media audio visual yang dilakukan, dipeoleh hasil Validasi Ahli Media ahli media dengan jumlah skor 53 dengan ratarata 3,5. Ada lima kategori yang dapat dijadikan sebagai acuan yaitu: a) $X>63$ (Sangat Baik), b) $51<X \leq 63$ (Baik), c) $39<X \leq 51$ (Cukup), d) $27<X \leq 39$ (Kurang), e) $\mathrm{X} \leq 27$ (Sangat Kurang). Dari hasil analisis tersebut dapat diketahui bahwa produk berupa media audio visual berbasis kearifan memperoleh jumlah skor adalah 53 yang berada pada rentang/interval $51<X \leq 63$ yang artinya bahwa media berbasis kearifan lokal Lombok memenuhi kategori "Baik" dan layak digunakan untuk mengambil data dengan revisi sesuai saran.

Hasil validasi oleh ahli materi terhadap media audio visual berbasis kearifan lokal daerah diperoleh hasil validasi dari ahli materi yaitu dengan jumlah skor 49 dengan rata-rata 4,9. Ada lima kategori yang dapat dijadikan sebagai, acuan yaitu:a) $X>42,006$ (Sangat Baik), b) 34,002 $<X \leq 42,006$ (Baik), c) 25,998 $<X \leq 34,002$ (Cukup), d) 17,994 $<\mathrm{X} \leq 25,998$ (Kurang), e) $\mathrm{X} \leq 17,994$ (Sangat Kurang). Dari hasil analisis tersebut dapat diketahui bahwa produk berupa media audio visual berbasis kearifan memperoleh jumlah skor aktual rata-rata adalah 4,9 yang berada pada rentang/interval $\mathrm{X}>$ 42,006 yang artinya bahwa media berbasis kearifan lokal Lombok memenuhi kategori "Sangat Baik" dan layak digunakan untuk mengambil data dengan revisi sesuai saran.

Berdasarkan angket respon siswa mengenai tanggapannya terhadap media audio visual berbasis kearifan lokal daerah Lombok pada Tema 1 Indahnya kebersamaan. Dari angket yang sudah disebarkan ke 36 orang siswa, dengan jumlah responden secara keselurahan sebesar 360. Jumla responden yang menjawab 
"Ya"sebanyak 329 setelah dibagi dengan kesluruhan responden menjadi 91,4\%. Sedangkan Jumlah responden yang menjawab "Tidak" sebanyak 31 setelah dibagi dengan keseluruhan respondenmenjadi $8,6 \%$. Kriteria jawaban yang diberikan responden a) Persentase $81 \%$ - 100\% (sangat merespon), b) Persentase $61 \%-80 \%$ (merespon), c) Persentase 41\% - 60\% (cukup merespon), d) Persentase $21 \%-40 \%$ (tidak merespon), e) Persentase 0\% - 20\% (sangat tidak merespon). Dari kriteria jawaban yang diberikan responden sebesar 91,4\% dan berada pada rentang persentase $81 \%$ - 100\% dengan kategori "sangat merespon".Dengan demikian data tersebut menunjukkan bahwa respon siswa positif terhadap keterlaksanaan pembelajaran dengan penggunaan media audio visual berbasis kearifan lokal daerah Lombok.

Berdasarkan data hasil belajar siswa setelah dilakukan uji coba data yang diperoleh dari 36 orang siswa diantaranya 6 siswa mendapat nilai 100, 9 orang siswa mendapatkan nilai 90, 10 orang siswa mendapatkan nilai 80,4 orang siswa mendapatkan nilai 70,4 orang siswa mendapatkan nilai 60 , dan 3 orang siswa mendapatkan nilai 50 dengan KKM 70. Jumlah siswa tuntas sebanyak 29 orang dan jumlah siswa yang tidak tuntas sebanyak 7 orang. Data yang diperoleh menunjukkan bahwa secara klasikal nilai rata-rata yang diperoleh adalah 83,7 dengan ketuntasan klasikal siswa 80\%. Dapat disimpulkan bahwa pembelajaran dengan menggunakan media audio visual berbasis kearifan lokal pada Tema 1 Indahnya Kebersamaan dapat dikatakan efektif karena telah mencapai ketuntasan klasikal yang telah ditetapkan, yaitu $80 \%$.

Berdasarkan hasil validasi ahli media dengan skor rata-rata 3,5 dalam kategori "baik" dan hasil validasi ahli materi dengan skor rata-rata 4,9 dalam kategori "sangat baik", sehingga media audio visual tersebut sudah dikatakan layak digunakan dalam proses pembelajaran. Sedangkan untuk melihat respon siswa dalam proses pembelajaran menggunakan media audio visual yang dikembangkan dilihat dari data uji coba lapangan menggunakan angket respon siswa, hasil uji coba lapangan menunjukkan bahwa media audio visual berbasis kearifan lokal daerah Lombok yang dikembangkan dinilai baik oleh siswa, dilihat dari hasil uji coba lapangan siswa lebih bersemangat dan lebih aktif dalam proses pembelajaran. Hasil akhir yang diperoleh atau rata-rata angket respon siswa pada uji coba lapangan adalah 91,4\% dalam 
kategori "sangat merespon". Setelah melihat respon siswa, peneliti juga melihat hasil belajar siswa setelah menggunakan media audio visual yang dikembangkan dalam proses pembelajaran. Adapun hasil belajar siswa yang diperoleh setelah menggunakan media audio visualyang dikembangkan yaitu, dapat meningkatkan pemahaman materi siswa dan dinyatakan efektif dari segi pencapaian hasil belajar siswa berdasarkan data yang diperoleh menunjukkan bahwa ketuntasan klasikal siswa mencapai lebih dari $50 \%$ yaitu $80 \%$ ini menunjukkan bahwa lebih banyak siswa yang tuntas daripada yang tidak tuntas. Dengan demikian, dapat disimpulkan bahwa media pembelajaran ini memiliki kualitas yang layak dan dapat diterima sebagai salah satu media pembelajaran pada Tema 1 Indahnya Kebersamaan.

Kelebihan dari media ini umum yaitu terdapat rangkuman dan soal yang sudah disediakan didalam vidio. Sedangkan kelemahan dari media audio visual ini diantaranya dari segi materi yang ada dalam media audio visual ini masih terbatas karena belum sepenuhnya membahas semua karifan lokal yang ada di Lombok dan dari segi penggunaannya hanya bisa digunakan oleh orang yang memahami tekhnologi.

\section{SIMPULAN}

Berdasarkan hasil penelitian dan pengembangan media audio visual berbasis kearifan lokal daerah Lombok pada Tema 1 Indahnya Kebersamaan kelas IV SDN 1 Danger, dapat disimpulkan beberapa hal yaitu: Hasil validasi media audio visual berbasis kearifan lokal daerah Lombok yaitu, dari ahli media dengans skor $(X=53)$ dengan rentang skor $51<\mathrm{X} \leq 63$ yang berada padakategori "baik" dan dari ahli materi dengan skor $(X=49)$ dengan rentang skor $X>42,006$ yang berada pada kategori "sangat baik". Adapun respon siswa dalam proses pembelajaran menggunakan media audio visual yang dikembangkan yaitu, diperoleh rata-rata angket respon siswa 91,4\% yang berada pada berada pada rentang persentase $81 \%$ $100 \%$ kategori "sangat merespon". Selanjutnya untuk hasil belajar siswa yang sudah dilakukan menunjukkan bahwa ketuntasan klasikal siswa yaitu $80 \%$. 


\section{DAFTAR PUSTAKA}

Agus Suryono. (2012). Birokrasi dan Kearifan Lokal. Malang: Universitas Brawijaya Press.

Azhar Arsyad. (2017). Media Pembelajaran. Jakarta: PT. Raja Grafindo Persada.

Daryanto. (2013). Media Pembelajaran: Peranannya Sangat Penting dalam Mencapai Tujuan Pembelajaran. Yogyakarta: Penerbit Gava Media.

Hamdani.(2011). Strategi Belajar Mengajar.Bandung : CV Pustaka Setia

Ibrahim, D. S. M., Aswasulasikin, A., \& Hidayatullah, M. (2019). Bahan Ajar Berhitung Cepat Dengan Aplikasi Game Adobe Flash Untuk Pembelajaran Matematika Di Sekolah Dasar. Jurnal DIDIKA: Wahana Ilmiah Pendidikan Dasar, 5(2), 86-93.

Marfai, M.A. (2013). Pengantar Etika Lingkungan Dan Kearifan Lokal . Yogyakarta: Gadjah Mada University Press

Nana Syaodih \& Sukmadinata.(2013). Metode Penelitian Pendidikan. PT Bandung Remaja Rosdakarya

Rusman, dkk.(2013). Pembelajaran Berbasis Teknologi Informasi Pendidikan. Jakarta: PT Raja Grafindo Persada.

Sugiyono. 2015. Metode Penelitian Kuantitatif Kualitatif dan R\&D. Bandung: Alfabeta.

Sururuddin, M., Hadi, Y. A., \& Burhanuddin, B. (2019). Pengembangan Media Audio Visual Menggunakan Macromedia Flash Pada Mata Pelajaran IPS Tahun Pelajaran 2018-2019. Jurnal DIDIKA: Wahana Ilmiah Pendidikan Dasar, 5(1), 24-31.

Tri Joko Haryanto. (2014). Kearifan Lokal Pendukung Kerukunan Beragama Pada Komunitas Tengger Malang Jatim.Jurnal Analisa, Volume 21, Nomor 2, hal. 201-213.Diunduh dari https://www.academia.edu/18682396 pada tanggal 7 April 2019

Yudhi Munadi. (2013). Media Pembelajaran (Sebuah Pendekatan Baru).Jakarta: Gaung Persada Press. 